Article

\title{
Transformation of Psoralen and Isopsoralen by Human Intestinal Microbial In Vitro, and the Biological Activities of Its Metabolites
}

\author{
Lu Liu, Lei Zhang, Ze-Xu Cui, Xiao-Yan Liu, Wei Xu and Xiu-Wei Yang * \\ State Key Laboratory of Natural and Biomimetic Drugs, Department of Natural Medicines, School of \\ Pharmaceutical Sciences, Peking University Health Science Center, Peking University, No. 38, Xueyuan Road, \\ Haidian District, Beijing 100191, China; a1534064875@163.com (L.L.); zhangyutian0619@163.com (L.Z.); \\ czx9738@163.com (Z.-X.C.); yanzi_89@163.com (X.-Y.L.); high-xu@163.com (W.X.) \\ * Correspondence: xwyang@bjmu.edu.cn; Tel.: +86-10-8280-1569; Fax: +86-10-8280-2724
}

Academic Editor: Gianni Sacchetti

Received: 28 October 2019; Accepted: 8 November 2019; Published: 12 November 2019

\begin{abstract}
Psoralen (P) and isopsoralen (IP) are the main active ingredients in the dried fruit of Psoralen corylifolia $\mathrm{L}$. (PC), with a wide range of pharmacology activities. The intestinal bacteria biotransformation plays a central role in the metabolism of the complex ingredients in traditional Chinese medicine (TCM). Our study aimed to investigated the metabolic profile of $\mathrm{P}$ and IP in the intestinal condition, co-cultured with human fecal bacteria anaerobically. Four bio-transforming products were obtained, including 6,7-furano-hydrocoumaric acid (P-1) and 6,7-furano-hydrocoumaric acid methyl ester (P-2), which transformed from $\mathrm{P}$, and 5,6-furano-hydrocoumaric acid (IP-1) and 5,6-furano-hydrocoumaric acid methyl ester (IP-2), which were transformed from IP. It is worth mentioning that IP-2 is a new compound that has not been published. Their structures were analyzed based on their spectroscopic data. Moreover, a highly sensitive ultra-performance liquid chromatography tandem mass spectrometry (UPLC-MS/MS) method was used to characterize the metabolic pathways of P, IP, and their bio-transforming products in the reaction samples. In addition, the dampening effects against the oxidative stress of $\mathrm{P}, \mathrm{IP}$, and their bio-transforming products by human intestinal flora were estimated in vitro via the human colorectal cells (HCT116) and heterogeneous human epithelial colorectal adenocarcinoma cells (Caco-2) cell lines. The results showed that the metabolites have stronger activity than $\mathrm{P}$ and IP, which possibly provides a basis for elucidating the treating mechanisms of PC extract against inflammatory bowel disease.
\end{abstract}

Keywords: Psoralea corylifolia L.; psoralen; isopsoralen; LC-MS/MS; human intestinal flora; oxidative stress

\section{Introduction}

Traditional Chinese medicine (TCM) have been used to guide clinical treatment by herbalist doctors for thousands of years. Psoralea corylifolia L. (PC), which is part of the family Fabaceae, is extensively used in China, India, and many other countries [1]. In China, the extract of PC fruits is one of the most commonly used tonic herbs, having the effects of kidney impotence and warming spleen, which could treat diarrhea effectively, and has been included by Pharmacopoeia of People's Republic of China (2015) [2]. Being familiar with its vernacular names in India, the most widely used types are Babachi (Hindi), Bemchi, Bawchi, and so on. [3]. However, several reports have indicated that PC is regarded as an endangered medicinal plant in India, so the research of this plant has attracted much attentions [4,5]. Modern pharmacological studies have shown that the dried fruit of the plant has anti-bacterial [6], anti-diabetic [7], anti-depressant [8], anti-oxidative [9], anti-fungal [10], anti-inflammatory [11], and many other effective activities. 
Phytochemical examinations revealed that various components, including coumarins, flavonoids, phenols, monoterpenoids, quinines, sesquiterpenoids, triterpenoids, aliphatic acid, and some other components, have been isolated from PC [12]. Among them, coumarins have been proven to be the main active constituents of $\mathrm{PC}$, and the highest ingredients in $\mathrm{PC}$ are psoralen $(\mathrm{P})$ and isopsoralen (IP; structures shown in Figure 1). Previous studies have reported their therapeutic effects, such as antitumoral, antiamnesic [13,14], antibacterial, and estrogen-like effects $[15,16]$. More specifically, $\mathrm{P}$ and IP present a dose-dependent anticancer activity in oral carcinoma and erythroleukemia cells [17], respectively. Also, P and IP exhibit a significant anti-oomycete activity against Phytophthora infestans [18]. $\mathrm{P}$ has been demonstrated to adjust the function of osteoblasts in mice that suffer from the tumor, and resulted in the growth inhibition of the breast cancer cell in the bone environment, which could also be understood that $\mathrm{P}$ could inhibit the cancer migration of breast cancer to bone [19]. Furthermore, scientists have found that five isolated components from the seeds of PC exhibited a tyrosinase inhibitory activity [20]. The antioxidant activities of seven compounds, including P from PC extracts, were quantitatively estimated by the electron spin resonance (ESR) method, for which the results illustrate that these compounds expressed different degrees of antioxidant activity [21]. Furthermore, it is well established that oxidative stress is common in inflammatory bowel diseases (IBDs), and that antioxidants are usually recommended for the treatment [22], so we have thought more along the line of antioxidant stress. Furthermore, our previous report suggested the potential value of the Fruetus psoraleae compounds in alzheimer's disease (AD) prevention and treatment [23,24].

The oral administration for drugs is the most convenient method for the majority TCM-their active components are subjected to absorption, distribution, metabolism, and excretion in individuals. Moreover, intestinal bacteria transformation is a crucial link, which lead to generating more active compounds in the alimentary tract. It is a reasonable way to look for new leading compounds based on the physiological disposition process of the compounds [25]. At present, many plasma pharmacokinetic studies of P and IP have been reported [26], and several researches indicate that P and IP show a fast-oral absorption with the enterohepatic circulation. Our previous studies have demonstrated that some coumarins in PC could penetrate the blood-brain barrier rapidly and accumulate in the brain [27]. The tissue distribution essay result shows that the coumarins in the PC extract have a high bioavailability, and they are rapidly and widely distributed into tissues [26,28]. Combined with the recent progresses of pharmacological activities mentioned above, we have every reason to believe that the explication of the dynamic process in the organisms of PC will be a key step to understanding their pharmacodynamic material basis. The transformation of P and IP by intestinal bacteria, however, has rarely been studied. Therefore, it is necessary to investigate the biotransformation of $\mathrm{P}$ and IP by incubated human intestinal bacteria in vitro. Moreover, the related activities of $\mathrm{P}$ and IP, and their transformation products have been evaluated, such as being able to dampen the effects of oxidative stress.

\section{Results and Discussion}

\subsection{Metabolic Processing of $P$ and IP by Human Intestinal Bacteria}

$\mathrm{P}$ and IP were separately incubated with the bacterial suspension anaerobically, and the metabolic samples were incubated for 12, 24, and $48 \mathrm{~h}$, then extracted with ethyl acetate (EtOAc), and analyzed by HPLC. What needs illustration is that several organic solvents were tested, including EtOAc and water-saturated $\mathrm{n}-\mathrm{BuOH}$, as well as firstly extracting with EtOAc, then water-saturated $n-\mathrm{BuOH}$. Consequently, the bacterial suspension was fully extracted with EtOAc., and water-saturated butanol was not chosen as the extraction reagent, so as to exclude unnecessary impurity. As shown in Figure S1, compared with the control sample (general anaerobic medium (GAM) and IP) and blank sample (incubation solution without analyses), two metabolites from IP were obtained. The metabolic pathway of $P$ was similar to IP. The chemical structures were evident by their spectra of infrared ray (IR), liquid chromatography-mass spectrometry (LC-MS), ${ }^{1}$ hydrogen-nuclear magnetic resonance $\left({ }^{1} \mathrm{H}-\mathrm{NMR}\right)$, 
${ }^{13}$ carbon nuclear magnetic resonance spectroscopy $\left({ }^{13} \mathrm{C}-\mathrm{NMR}\right)$, heteronuclear multiple quantum coherence (HMQC), heteronuclear multiple bond correlation (HMBC), and heteronuclear single quantum correlation (HSQC), and compared with the data reported in the published paper, which were consistent with the structure, being 6,7-furano-hydrocoumaric acid (P-1), 6,7-furano-hydrocoumaric acid methyl ester (P-2), and 5,6-furano-hydrocoumaric acid (IP-1). It deserves to be mentioned that IP-2 (5,6-furano-hydrocoumaric acid methyl ester) was confirmed as a new metabolite, which has never been published before. Among them, the amounts of P- 1 and IP- 1 were relatively large, which were the main biotransformation products of $\mathrm{P}$ and IP, respectively. The amounts of P-2 and IP-2 were relatively smaller than that for P-1 and IP-1. Despite this, all of the four transformation products were obtained by our research for probing into the biotransformation mechanism of P and IP in the human intestinal flora, which will be further discussed in the Discussion section. Moreover, the stability of the internal standard (I.S.) in the microflora solution was also performed, but no transformation products were generated. The structures of six compounds and I.S., as well as the ion pairs, are illustrated in Figure 1.

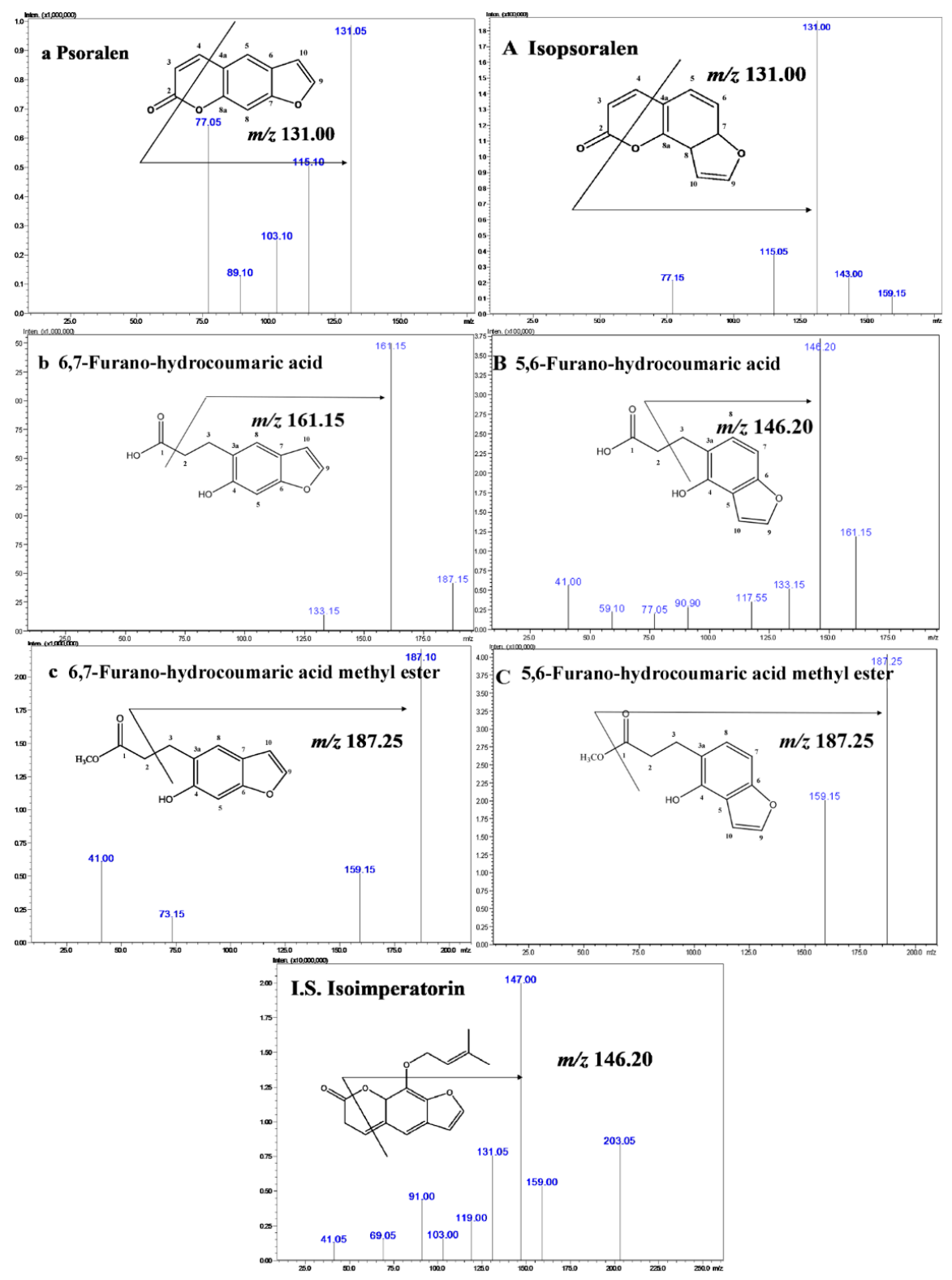

Figure 1. Chemical structures and MS/MS fragmentation patterns of psoralen (P), isopsoralen (IP), and their transformation products. 
Biotransformation products P-1 (101 mg) and P-2 (15 mg) were isolated from the extract of P, and IP-1 (121 mg) and IP-2 (8 mg) were isolated from the extract of IP. The chemical structures of the transformed products are listed in Figure 2. The transformation processes were monitored by an Agilent HPLC-DAD system (Agilent, Waldbronn, Germany) at $245 \mathrm{~nm}$, the details of which are discussed in the supporting information (Figure S1, Table S2, and the section of "Procedures and Conditions of Chemical Separation").

P-1: $\mathrm{C}_{11} \mathrm{H}_{10} \mathrm{O}_{4}$, white powder. IR (KBr) $v_{\max } 3420.82,1080.81 \mathrm{~cm}^{-1}$. ESI MS $m / z 205.15[\mathrm{M}-\mathrm{H}]^{-} .{ }^{1} \mathrm{H}$

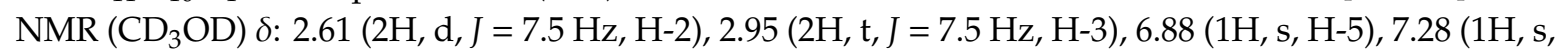
$\mathrm{H}-8), 7.51(1 \mathrm{H}, \mathrm{d}, J=2.1 \mathrm{~Hz}, \mathrm{H}-9), 6.64(1 \mathrm{H}, \mathrm{d}, J=2.2 \mathrm{~Hz}, \mathrm{H}-10) ;{ }^{13} \mathrm{C}$ NMR $\left(\mathrm{CD}_{3} \mathrm{OD}\right) \delta: 178.0(\mathrm{C}-1)$, 35.9 (C-2), 27.5 (C-3), 125.2 (C-3a), 154.6 (C-4), 98.3 (C-5), 156.2 (C-6), 121.0 (C-7), 122.2 (C-8), 144.6 (C-9), 107.2 (C-10). Compared with the data reported in the published paper [29], this compound was identified as 6,7-furano-hydrocoumaric acid.

P-2: $\mathrm{C}_{12} \mathrm{H}_{12} \mathrm{O}_{4}$, white powder. IR (KBr) $v_{\max } 3416.77,1734.91 \mathrm{~cm}^{-1}$. ESI MS m/z $219.15[\mathrm{M}-\mathrm{H}]^{-}$. ${ }^{1} \mathrm{H}-\mathrm{NMR}\left(\mathrm{CD}_{3} \mathrm{OD}\right) \delta: 2.64(2 \mathrm{H}, \mathrm{d}, J=7.8 \mathrm{~Hz}, \mathrm{H}-2), 2.95(2 \mathrm{H}, \mathrm{t}, J=7.8 \mathrm{~Hz}, \mathrm{H}-3), 6.88(1 \mathrm{H}, \mathrm{d}, J=0.9 \mathrm{~Hz}$, H-5), $7.26(1 \mathrm{H}, \mathrm{d}, J=0.9 \mathrm{~Hz}, \mathrm{H}-8), 7.52(1 \mathrm{H}, \mathrm{d}, J=2.2 \mathrm{~Hz}, \mathrm{H}-9), 6.65(1 \mathrm{H}, \mathrm{dd}, J=2.2 \mathrm{~Hz}, \mathrm{H}-10), 3.64(3 \mathrm{H}$, s, OMe); ${ }^{13} \mathrm{C}$ NMR (100 MHz, CD 3 OD) $\delta: 175.9$ (C-1), 35.4 (C-2), 27.5 (C-3), 126.3 (C-3a), 154.6 (C-4), 98.2 (C-5), 156.2 (C-6), 121.2 (C-7), 122.2 (C-8), 144.6 (C-9), 107.1 (C-10), 52.0 (OMe). Compared with the data reported in the published paper [29], this compound was identified as 6,7-furano-hydrocoumaric acid methyl ester.

IP-1: $\mathrm{C}_{11} \mathrm{H}_{10} \mathrm{O}_{4}$, white powder. IR (KBr) 3423.79, 1053.94 $\mathrm{cm}^{-1}$. ESI MS m/z $205.10[\mathrm{M}-\mathrm{H}]^{-}$. ${ }^{1} \mathrm{H}$ NMR $\left(\mathrm{CD}_{3} \mathrm{OD}\right) \delta: 2.60(2 \mathrm{H}, \mathrm{d}, J=7.8 \mathrm{~Hz}, \mathrm{H}-2), 2.96(2 \mathrm{H}, \mathrm{t}, J=7.8 \mathrm{~Hz}, \mathrm{H}-3), 6.92(1 \mathrm{H}, \mathrm{d}, J=8.5 \mathrm{~Hz}, \mathrm{H}-7), 7.03$ $(1 \mathrm{H}, \mathrm{d}, J=8.5 \mathrm{~Hz}, \mathrm{H}-8), 7.56(1 \mathrm{H}, \mathrm{d}, J=2.2 \mathrm{~Hz}, \mathrm{H}-9), 6.91(1 \mathrm{H}, \mathrm{d}, J=2.2 \mathrm{~Hz}, \mathrm{H}-10) ;{ }^{13} \mathrm{C}$ NMR $\left(\mathrm{CD}_{3} \mathrm{OD}\right)$ $\delta: 177.8$ (C-1), 35.9 (C-2), 26.6 (C-3), 121.1 (C-3a), 149.2 (C-4), 118.3 (C-5), 156.8 (C-6), 103.8 (C-7), 127.5 (C-8), 144.6 (C-9), 104.7 (C-10). Compared with the data reported in the published paper [30], this compound was identified as 5,6-furano-hydrocoumaric acid.

IP-2: Obtained as a white powder, the molecular formula was deduced to be $\mathrm{C}_{11} \mathrm{H}_{12} \mathrm{O}_{4}$, based on the quasi-molecular ion peak in the negative HR-ESI-MS at $m / z 219.0656$ ([M - H $]^{-}$, calculated 219.0657). The IR spectrum displayed strong absorption bands at $1734.91 \mathrm{~cm}^{-1}$, indicating an ester group, and $3424.17 \mathrm{~cm}^{-1}$, suggestive of the hydroxyl function, and $1054.17 \mathrm{~cm}^{-1}$, suggestive of the propyl structure (C-C-C). The complete unambiguous assignments for the ${ }^{1} \mathrm{H}$ and ${ }^{13} \mathrm{C}$ NMR signals of IP-2 were made by a combination of the ${ }^{1} \mathrm{H}-{ }^{1} \mathrm{H}$ COSY, HSQC, HMBC, and nuclear overhauser effect spectroscopy (NOESY) spectra, suggesting the presence of a methoxy group at $\delta 3.64(3 \mathrm{H}, \mathrm{s}, \mathrm{OMe})$, one olefinic at $\delta$ $7.56(1 \mathrm{H}, \mathrm{d}, J=2.2 \mathrm{~Hz}, \mathrm{H}-9), 6.91(1 \mathrm{H}, \mathrm{br} \mathrm{d}, J=2.2 \mathrm{~Hz}, \mathrm{H}-10)$. The other NMR spectral data of IP-2 are listed as below, namely: ${ }^{1} \mathrm{H}$ NMR $\left(\mathrm{CD}_{3} \mathrm{OD}\right) \delta: 2.63(2 \mathrm{H}, \mathrm{d}, J=7.8 \mathrm{~Hz}, \mathrm{H}-2), 2.97(2 \mathrm{H}, \mathrm{t}, J=7.8 \mathrm{~Hz}, \mathrm{H}-3)$, $6.91(1 \mathrm{H}$, br d, $J=8.4 \mathrm{~Hz}, \mathrm{H}-7), 7.01(1 \mathrm{H}, \mathrm{d}, J=8.4 \mathrm{~Hz}, \mathrm{H}-8) ;{ }^{13} \mathrm{C} \mathrm{NMR}\left(100 \mathrm{MHz}, \mathrm{CD}_{3} \mathrm{OD}\right) \delta: 175.9$ (C-1), 35.7 (C-2), 26.7 (C-3), 120.8 (C-3a), 149.2 (C-4), 118.2 (C-5), 156.9 (C-6), 103.7 (C-7), 127.5 (C-8), 144.7 (C-9), 104.7 (C-10), 52.2 (OMe). It is not difficult to find that the NMR spectral data of IP-2 were found be like IP-1, so we can reasonably conclude that IP-2 is the methyl-esterification product of IP-1. Thus, the structure of the new compound was unambiguously identified as 5,6-furano-hydrocoumaric acid methyl ester. The related spectrograms are listed in the supporting information (Figures S2-S8). 


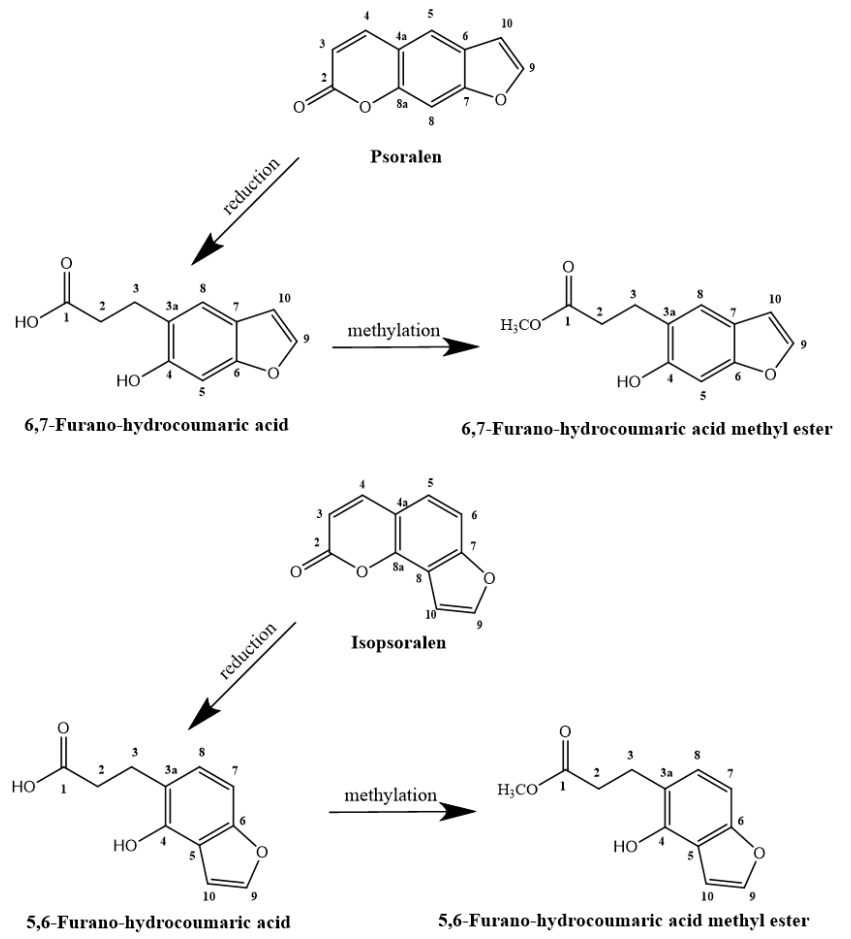

Figure 2. The possible metabolic pathways of $\mathrm{P}$ and IP by human intestinal bacteria.

\subsection{Method Validation of the Archetype and Metabolites}

\subsubsection{UPLC-MS/MS Condition Optimization}

The initial step was to optimize the precursor, product ions, and other parameters of six compounds and I.S. We found that P, IP, and I.S. presented a stronger ionization in the positive ion mode, while the other four metabolites presented a stronger ionization in the negative ion mode. The advantage of the instrument we have chosen is that it could analyze the samples in both the positive and negative mode simultaneously. Furthermore, the Q1 pre-bias, Q3 pre-bias, and collision energy (CE) were optimized to enhance the ion transmissions during the experiment. The parameters that were optimized are listed in Table 1. Multiple groups of the mobile phase, including MeOH-water and can-water, which contain different $\mathrm{pH}$ modifiers (ammonium acetate, formic acid, and ammonia), were tried to choose the optimal mobile phase system. Finally, a 1-mM ammonium acetate aqueous solution (A) and acetonitrile (ACN; B) were chosen as the mobile phase, which produced the best response and sensitivity. The gradient elution program is shown in Table S1, with the flow rate set as $0.35 \mathrm{~mL} / \mathrm{min}$, while the column temperature is $30^{\circ} \mathrm{C}$.

Table 1. Optimized multiple reaction monitoring (MRM) parameters of five compounds and internal standard (I.S.) in mass detection.

\begin{tabular}{|c|c|c|c|c|c|c|c|}
\hline Analyte & MRM & $\begin{array}{c}\text { Precursor } \\
\text { Ion-Product Ion } \\
(\mathrm{m} / \mathrm{z})\end{array}$ & $\begin{array}{l}\text { Q1 Pre-Bias * } \\
\text { (V) }\end{array}$ & $\begin{array}{c}\text { Collision } \\
\text { Energy (V) }\end{array}$ & $\begin{array}{l}\text { Q3 Pre-Bias * } \\
\text { (V) }\end{array}$ & $\begin{array}{l}\text { Dwell Time } \\
\text { (msec) }\end{array}$ & $\begin{array}{l}\text { Retention Time } \\
\text { (min) }\end{array}$ \\
\hline $\mathrm{P}$ & MRM (+) & $187.10-131.05$ & -14.0 & -27.0 & -23.0 & 100.0 & 3.351 \\
\hline $\mathrm{P}-2$ & MRM (-) & $219.15-187.10$ & 16.0 & 11.0 & 18.0 & 100.0 & 3.873 \\
\hline IP & MRM (+) & $187.00-131.95$ & -14.0 & -23.0 & -22.0 & 100.0 & 3.421 \\
\hline IP-1 & MRM (-) & 205.10-146.15 & 15.0 & 22.0 & 28.0 & 100.0 & 0.842 \\
\hline
\end{tabular}

*: Q1 pre-bias and Q3 pre-bias: voltage enhance the ion transmission of the precursor ion and the product ion; dwell time: residence time during an acquisition point. 


\subsubsection{The Assay Validation}

Two sets of chromatographic peaks of the three constituents and I.S. showed very good resolutions in Figure 3. The bacterial suspension samples show no interfering peaks from the endogenous substances. Figure 3 exhibits the representative multiple reaction monitoring (MRM) chromatograms of the blank heat-inactivated incubation solution (A); a spiked bacterial suspension sample with the components and the I.S. (LQC, B); and the sample obtained at $12 \mathrm{~h}$ after the biotransformation of P/IP (C). P, P-1, P-2, IP, IP-1, IP-2, and I.S. were eluted at 3.351, 0.768, 3.873, 3.421, 0.842, 4.030, and 6.245 min in an LQC sample, respectively.

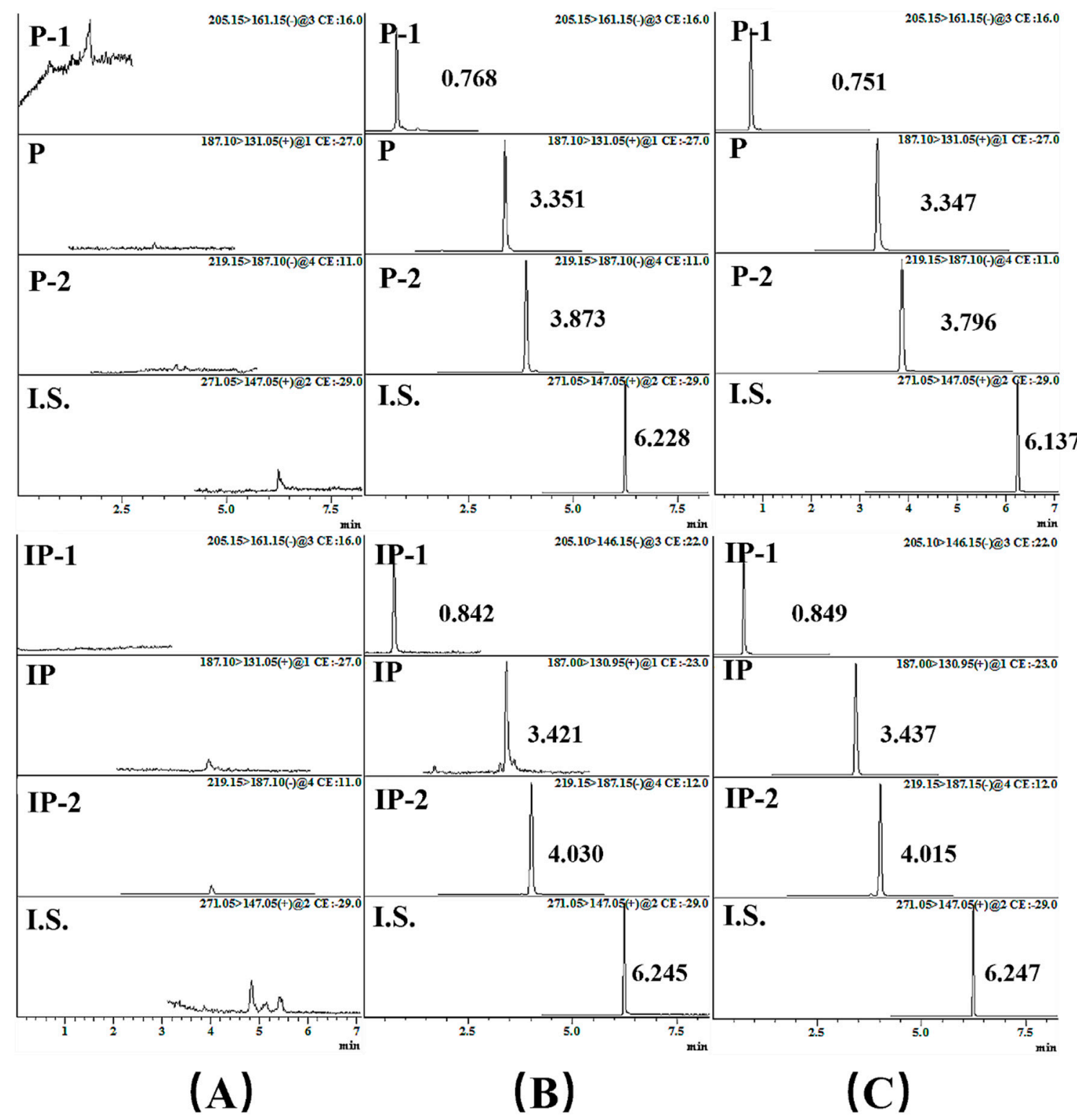

Figure 3. The typical MRM chromatograms with different disposal manners; (A) blank bacterial suspension; (B) blank bacterial suspension spiked with the six analytes and I.S. (LQC); (C) the chromatograms of the six components and I.S. in an active bacterial suspension, which were obtained at $12 \mathrm{~h}$.

As shown in Table 2, all the components presented a good linearity for all of the correlation coefficients $\left(r^{2}\right)$, which were $\geq 0.9906$. In general, a detector of the signal to noise $(\mathrm{S} / \mathrm{N})$ ratio of 3:1 was denoted as the lower limit of detection (LLOD), and 10:1 as the lower limit of quantitation (LLOQ). 
The LLODs of P, P-1, P-2, IP, IP-1, and IP-2 were 2.24, 2.65, 1.01, 2.53, 2.23, and $1.07 \mathrm{ng} / \mathrm{mL}$, respectively, and the LLOQs of P, P-1, P-2, IP, IP-1, and IP-2 were 4.88, 5.30, 2.02, 5.06, 4.46, $2.14 \mathrm{ng} / \mathrm{mL}$, respectively, which were suitable as the thresholds for the quantitation of the components.

As shown in Table 3, the results of the precision and accuracy indicated that the established method is satisfactory to analyze the six components in the human intestinal bacteria incubation system. The intraday and interday precision (Relative Standard Deviation; RSD\%) of all of the QC samples were less than $13.69 \%$, and the accuracies (RE\%) ranged from $-10.26 \%$ to $12.43 \%$.

Table 2. The regression data, lower limit of quantitations (LLOQs), and lower limits of detections (LLODs) of six compounds in human intestinal flora.

\begin{tabular}{cccccc}
\hline Analytes & Regression Equation & $r^{2}$ & $\begin{array}{c}\text { Linear } \\
\text { Range }\end{array}$ & LLOQ * & LLOD * \\
\hline P & $\mathrm{y}=46.4226 \mathrm{x}+198.909$ & 0.9977 & $4.88-2440$ & 4.88 & 2.44 \\
P-1 & $\mathrm{y}=318.924 \mathrm{x}+316.47$ & 0.9921 & $5.30-2650$ & 5.30 & 2.65 \\
P-2 & $\mathrm{y}=48.9102 \mathrm{x}+1577.72$ & 0.9931 & $2.02-1010$ & 2.02 & 1.01 \\
$\mathrm{IP}$ & $\mathrm{y}=227.105 \mathrm{x}-2813.5$ & 0.9939 & $5.06-2530$ & 5.06 & 2.53 \\
$\mathrm{IP}-1$ & $\mathrm{y}=226.079 \mathrm{x}-1952.0$ & 0.9906 & $4.46-2230$ & 4.46 & 2.23 \\
$\mathrm{IP}-2$ & $\mathrm{y}=854.015 \mathrm{x}-2543.2$ & 0.9957 & $2.14-1070$ & 2.14 & 1.07 \\
\hline
\end{tabular}

*: The linear range, LLOQ and LLOD units of compounds in human intestinal flora are $\mathrm{ng} / \mathrm{mL}$.

Table 3. Precision and accuracy of the determination of six compounds in the human intestinal flora $(n$ $=18$, six replicates per day for three days).

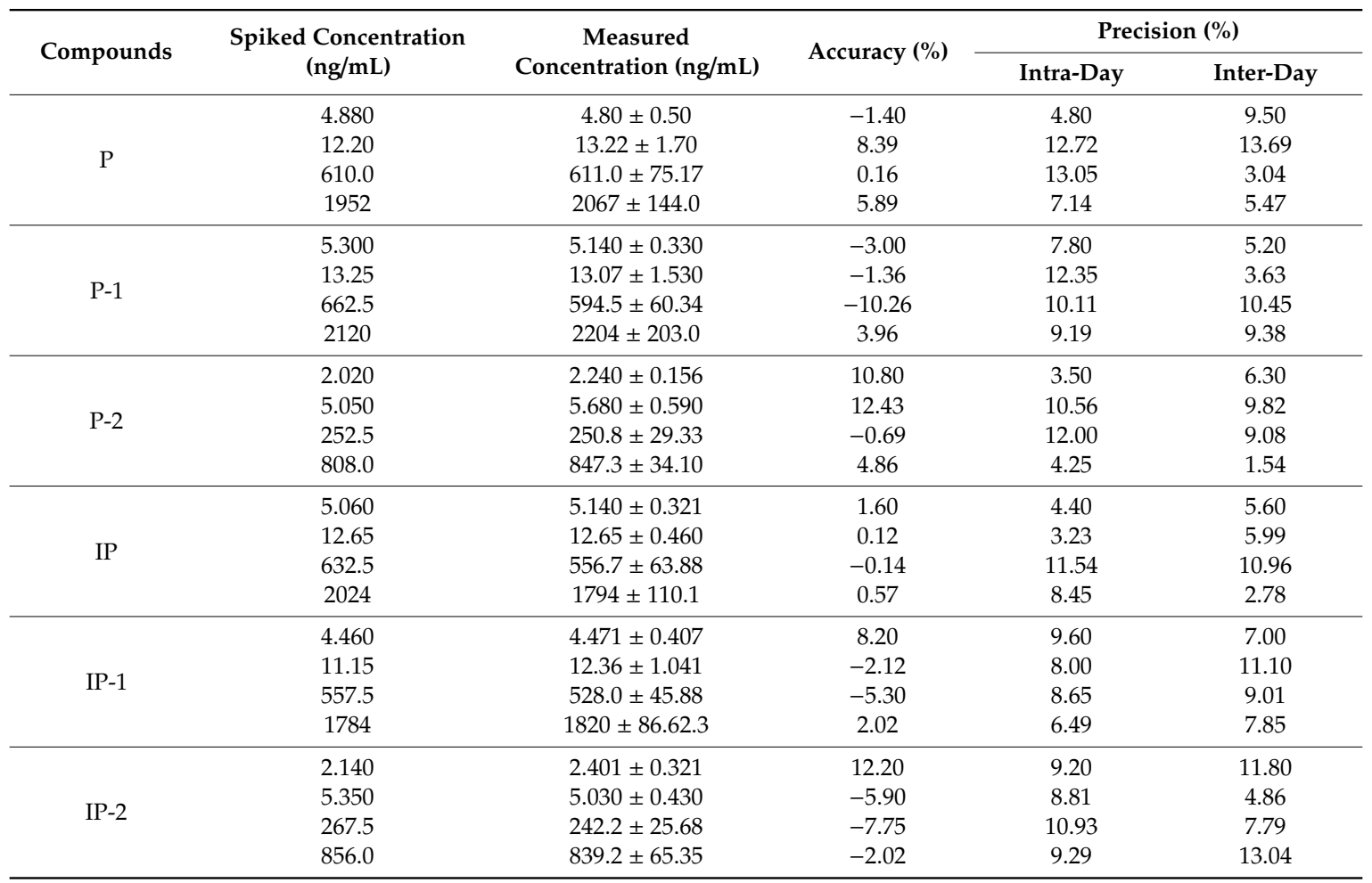

The extraction recovery and matrix effects experiments also have been established. The extraction recoveries were within the range of $82.04 \% \pm 8.58 \%-98.24 \% \pm 12.54 \%$. The matrix effects of all of the compounds were acceptable. with the values of $83.88 \% \pm 14.10 \%-110.48 \% \pm 10.38 \%$ in the heat-inactivated incubation solution (Table 4). Liquid-liquid extraction with EtOAc was a workable method for the analysis of the components and the I.S. The extraction recoveries and the matrix effects of I.S. were $87.75 \% \pm 12.45 \%$ and $87.89 \% \pm 5.89 \%$, respectively. 
Table 4. Matrix effects and extraction recovery for the analytes in human intestinal flora $(n=6)$.

\begin{tabular}{cccccc}
\hline \multirow{2}{*}{ Compounds } & $\begin{array}{c}\text { Spiked Concentration } \\
(\mathbf{n g} / \mathbf{m L})\end{array}$ & \multicolumn{2}{c}{ Matrix Effect } & \multicolumn{2}{c}{ Extraction Recovery } \\
\cline { 3 - 5 } & 12.20 & 86.87 & 5.68 & 98.24 & 12.54 \\
$\mathbf{n}$ & 610.0 & 88.37 & 7.94 & 95.99 & 5.57 \\
& 1952 & 98.49 & 11.52 & 91.86 & 5.12 \\
\hline \multirow{2}{*}{ P-1 } & 13.25 & 89.77 & 3.54 & 85.82 & 8.49 \\
& 662.5 & 101.14 & 9.56 & 94.81 & 4.10 \\
& 2120 & 99.26 & 10.55 & 89.49 & 13.53 \\
\hline \multirow{2}{*}{ P-2 } & 5.05 & 110.48 & 10.38 & 97.17 & 6.51 \\
& 252.5 & 96.99 & 4.52 & 96.02 & 4.84 \\
IP & 808 & 86.87 & 4.77 & 90.48 & 6.39 \\
\hline \multirow{2}{*}{ IP-1 } & 12.63 & 91.15 & 10.80 & 95.39 & 4.67 \\
& 632.5 & 95.51 & 3.37 & 91.31 & 4.72 \\
IP-2 & 2024 & 92.37 & 4.18 & 89.94 & 2.75 \\
\hline & 11.15 & 94.00 & 7.38 & 89.65 & 3.87 \\
& 557.5 & 93.53 & 7.86 & 87.95 & 9.78 \\
\hline & 1784 & 98.19 & 8.75 & 82.04 & 8.58 \\
\hline
\end{tabular}

The stability of the six analytes was investigated under the given conditions, illustrated in Table S3 in the supporting information. The concentrations obtained ranged from $-14.41 \%$ to $14.61 \%$ of their nominal concentrations, which suggests that the analytes were stable in the heat-inactivated incubation solution after storage for $4 \mathrm{~h}$ at an ambient temperature and being kept at $4{ }^{\circ} \mathrm{C}$ for $12 \mathrm{~h}$.

\subsection{Time Course of the Biotransformation of P and IP by Human Intestinal Flora}

Figure $4 \mathrm{~A}, \mathrm{~B}$ shows the time course of the biotransformation of $\mathrm{P}$ and IP at a dose of $0.15 \mathrm{mg} / \mathrm{mL}$, respectively. Because of the similar metabolic pathway of $\mathrm{P}$ and IP, we used $\mathrm{P}$ as an example to discuss the metabolic process of $\mathrm{P}$ and IP incubated with human fecal microflora. The results indicated that $\mathrm{P}$ was almost completely consumed $12 \mathrm{~h}$ after the start of incubation, and the other biotransformation products were dynamic generation. The ring structure of $\mathrm{P}$ depends on the ester bond, which could easily break in a strong environment, such as the harsh alkali conditions and the metabolism, by digestive enzymes from the intestine. As a result, $\mathrm{P}$ could be further metabolized by ring splitting to form a further product, $\mathrm{P}-1$. The hydroxy phenylacetic acid derivative of $\mathrm{P}$ increased in the first $8 \mathrm{~h}$, and was then maintained smoothly. The product P-2 was produced gradually with a much lower conversion than P-1, which suggests that P-1 could be a biotransformation intermediate. Moreover, $\mathrm{P}-2$ is the methylate of P-1, which could also have been available to support this viewpoint. After about $12 \mathrm{~h}$ of incubation, $\mathrm{P}$ changed more and more slowly, and finally it tended to steady. Then, after $16 \mathrm{~h}$, the conversion degree of all of the analytes started to level off. Furthermore, the transformation efficiency of $\mathrm{P}$ was a little more than IP, which might be related to the compounds' steric configuration. 


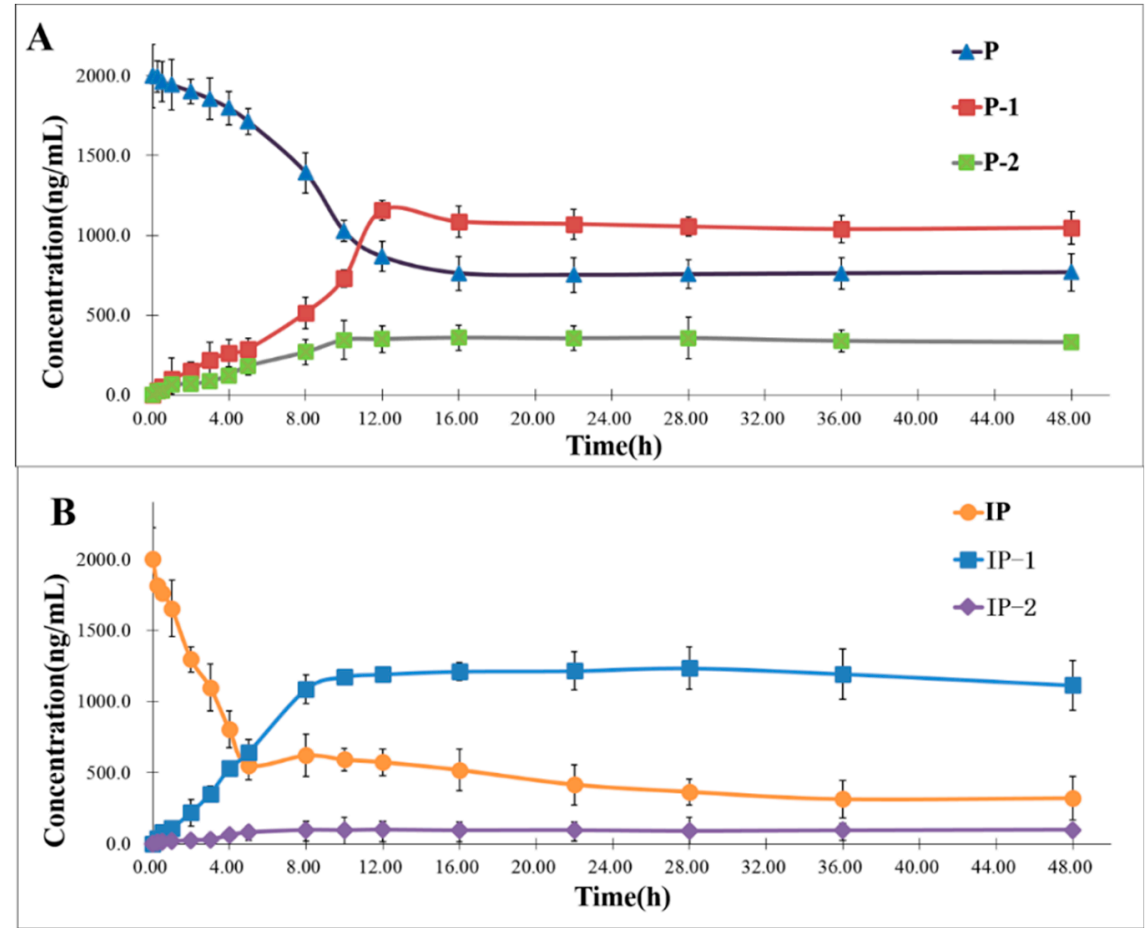

Figure 4. The time course of biotransformation of $\mathrm{P}(\mathrm{A})$ and IP (B) by active human intestinal flora $(n=3$, mean \pm standard deviation (SD).

\subsection{MTT Assay}

As shown in Figure 5A,B, the pretreatment of heterogeneous human epithelial colorectal adenocarcinoma cells (Caco-2) and human colorectal cells (HCT116) cells for $24 \mathrm{~h}$ with the co-culture of six analytes $(2.5,5$, and $10 \mu \mathrm{M})$ did not exhibit a cytotoxicity contrasted with the control cells, showing that the concentrations we chose did not injure the cell vitality during the process of the co-culture.

\subsection{Compounds Alleviate the Decreased Viability of HCT116 and Caco-2 Cells Induced by $\mathrm{H}_{2} \mathrm{O}_{2}$}

The damage of $\mathrm{H}_{2} \mathrm{O}_{2}$ on the HCT116 and Caco-2 cells was analyzed, and the concentration vs cell viability $(\mathrm{CV})$ relation graphs are shown in Figure $6 \mathrm{~A}, \mathrm{~B}$, respectively. However, after $\mathrm{H}_{2} \mathrm{O}_{2}$ exposure, the $C V$ was significantly decreased $(p<0.001)$ vs the control, at a concentration of $700 \mu \mathrm{M}(43 \%)$ for HCT116 and $900 \mu \mathrm{M}(47 \%)$ for Caco-2, which were the concentrations chosen as the model concentration. As shown in Figure 5A,B, P and IP have no obvious activities, while the biotransformation products of $\mathrm{P}$ and IP could be remarkable for improving the cell injury induced by $\mathrm{H}_{2} \mathrm{O}_{2}$. Take IP-2 for example, in the HCT116 cell line, it could increase the $\mathrm{CV}$ to $79 \%, 84 \%$, and $89 \%$ at $2.5,5,10 \mu \mathrm{M}$, respectively. In Caco-2 cell line, it could increase the CV to $62 \%, 74 \%, 82 \%$ at $2.5,5$, and $10 \mu \mathrm{M}$, respectively. All the four biotransformation products (P-1, P-2, IP-1, and IP-2) could obviously resist the cell damage in a dose-dependent way. The Cur group $(10 \mu \mathrm{M})$ was the positive control group, which could increase the CV to around $90 \%$ for the HCT116 and Caco-2 cell lines. The median effective dose (ED50) values were also calculated using SPSS statistics package v.20.0 (SPSS Inc., Chicago, USA). The ED50 values of P, P-1, P-2; IP, IP-1, and IP-2 were $18.08 \pm 4.32,8.54 \pm 3.14,7.78 \pm 0.11 ; 17.09 \pm 1.55,5.63 \pm 0.55$, and $3.49 \pm 0.11 \mu \mathrm{M}$, respectively. The ED50 value of Cur is $3.801 \pm 0.66 \mu \mathrm{M}$. 

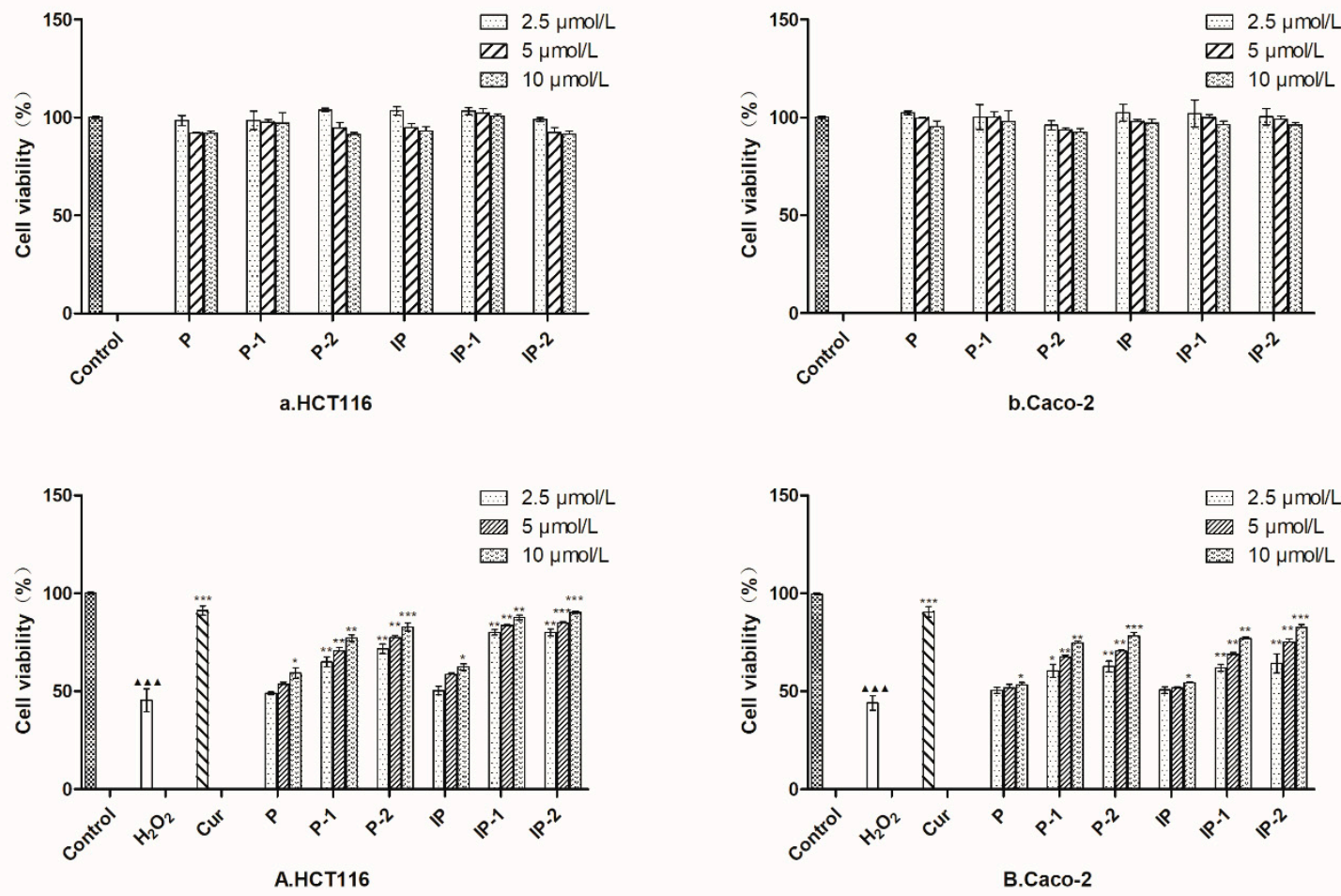

Figure 5. Cytotoxicity ((a) for HCT116 cell line; (b) for Caco-2 cell line) and the protect effects against $\mathrm{H}_{2} \mathrm{O}_{2}$-induced oxidative damage ((A) for HCT116 cell line; (B) for Caco-2 cell line) of P, IP, and their transformation products. The Cur group was the positive control group. Data are shown as the mean \pm $\mathrm{SD}(n=3) .{ }^{\mathbf{\Lambda} \boldsymbol{\Delta}} p<0.001$ vs control group; ${ }^{*} p<0.05,{ }^{* *} p<0.01,{ }^{* * *} p<0.001$ vs the $\mathrm{H}_{2} \mathrm{O}_{2}$ group.
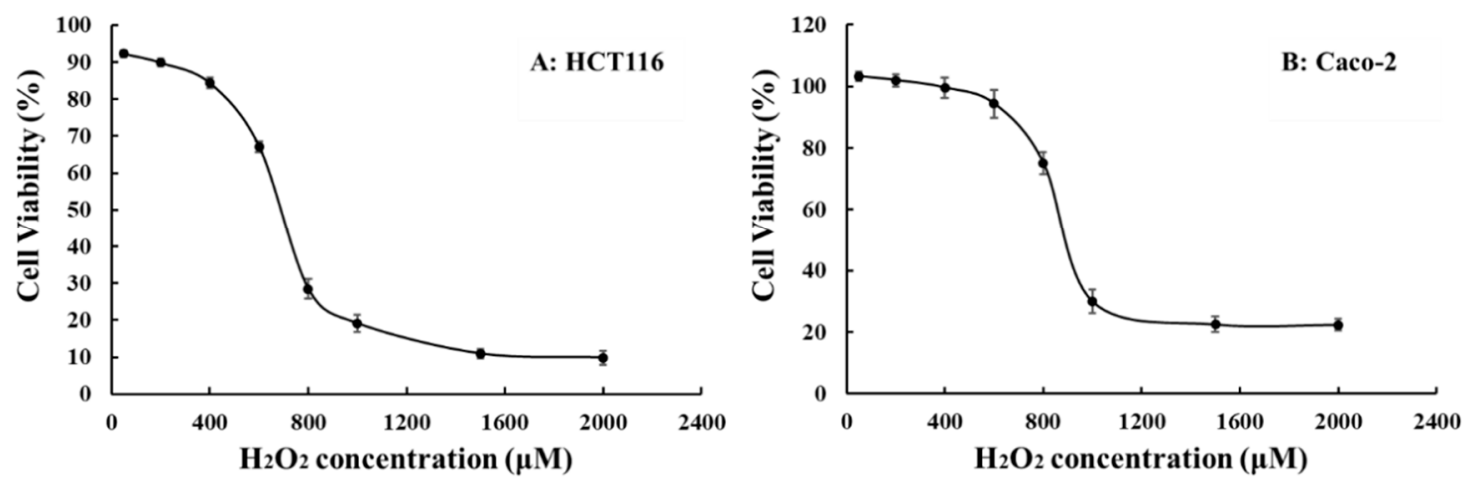

Figure 6. The cell viability of different cell lines against the $\mathrm{H}_{2} \mathrm{O}_{2}$ concentration ((A): human colorectal cells (HCT116); (B): heterogeneous human epithelial colorectal adenocarcinoma cells (Caco-2)).

\subsection{Discussion}

According to the chemical structures of the archetypes and their metabolites, tied together with the time-course curve, the main pathways of $\mathrm{P}$ and IP metabolism by human intestinal flora could be speculated in detail. As illustrated in Figure 2, the metabolism of the linear-type furanocoumarin P by human intestinal flora suggested that the main pathway involved a reduction at the $\alpha, \beta$-unsaturated lactone ring of the coumarin skeleton and methylation [29]. In the first step, the human intestinal flora was known to metabolize $\mathrm{P}$ by a reductive mechanism, leading to the occurrence of $\mathrm{P}-1$. As for P-2, it might be formed from the step of the esterification of P-1, by related enzymes from the intestinal bacteria. As the isomer of $\mathrm{P}$ (linear-type furanocoumarin), the conversion process of IP (angle-type furanocoumarin) was basically the same in the human intestinal flora, which is described in Figure 2. 
Compared with the time course of IP, we could find that the holistic reaction rate of $\mathrm{P}$ could to be relatively higher with the larger amount of transformation products and the longer reaction time. As shown in the time courses, the reduction and methylation reactor all tend to be stable after $8 \mathrm{~h}$ for IP, and $12 \mathrm{~h}$ for P. The concentration of IP-2 was just under the concentration of P-2, and while admitting more research is needed, we still think the structural differences between the isomers might account for these differences.

The pure products we obtained from the microbial transformed processes could be used for further pharmacological evaluation. As for the pharmacological activities' studies, PC has been discovered to have significant antioxidant, anticancer, and estrogenic activities. According to TCM, for hundreds of years, the seeds of PC have often been chosen as a main force in several formulas for treating IBD. It is well known that the overproduction of reactive oxygen species could incur oxidative stress, which plays a key role in the formation of IBDs. Treatment with $\mathrm{H}_{2} \mathrm{O}_{2}$ could induce oxidative stress and a degree of oxidative damage in Caco-2 cells [31] and HCT116 cells [32]. According to the relationship between the $\mathrm{H}_{2} \mathrm{O}_{2}$ levels and the survival rates of HCT116 and Caco-2 cell lines, the injured concentrations were chosen at $700 \mu \mathrm{M}$ and $900 \mu \mathrm{M}$ in this research, respectively. Guo et al. [33] evaluated the antioxidant activities of six compounds, including psoralidin, from PC extract, which exhibited strong antioxidant activities; however, $\mathrm{P}$ and IP do not possess any antioxidant activities either, which is consistent with the results of our experiments. Also, our research revealled that P-1, P-2, and IP-1, IP-2 had stronger antioxidant stress effects than coumarins (P and IP) [34]. To our best knowledge, there are very few studies about the metabolites of $\mathrm{P}$ and IP; through the research about the microbial transformation of $\mathrm{P}$, which was performed with the fungus Glomerella cingulate, Shinsuke et al. [29] obtained P-1 for the first time, and the $\beta$-secretase inhibitory activity of P- 1 and P-2 in vitro were proceeded. P- 2 was shown to have a $\beta$-secretase inhibitory activity, with an $\mathrm{IC}_{50}$ value of $0.84 \pm 0.06 \mathrm{mM}$. The bioactivities of IP-1 and IP-2 were first researched in our issue. Multiple literatures have reported that the metabolites of TCM performed stronger pharmacological activities than the original components, which are the final active compounds with the greatest importance $[35,36]$. Furthermore, the bioactivities of $\mathrm{P}$ and IP, especially their metabolites, exhibited great valuable to research among the topic of IBD.

\section{Experimental Section}

\subsection{Material and Conditions}

\subsubsection{Material and Reagents}

P and IP with $98 \%$ purity (Figure 1) were isolated from the fruits of PC by our research group; some of the chemical information are listed in the supporting information (Figures S9-S14), which were identified by the techniques of IR, MS, 1H-NMR, 13C-NMR, and HPLC analysis, as well as in comparison with the spectral data reported in the literature [37]. Isoimperatorin with $98 \%$ purity was used as an internal standard (I.S.; the structure illustrated in Figure 1) was isolated from the roots of Angelica dahurica cv. Yubaizhi by our research group [38], which was identified by the techniques of IR, MS, ${ }^{1} \mathrm{H}-\mathrm{NMR},{ }^{13} \mathrm{C}-\mathrm{NMR}$, and HPLC analysis. GAM (general anaerobic medium) was obtained from Beijing Land Bridge Technology Co., Ltd. (Beijing, China). LC-MS grade acetonitrile (ACN), methanol $(\mathrm{MeOH})$, and formic acid were purchased from Fisher Chemical (Fair lawn, NJ, USA). HPLC-grade ethyl acetate (EtOAc) and n-butanol $(\mathrm{n}-\mathrm{BuOH})$ were obtained from Beijing Chemical Works (Beijing, China). Deionized water was purified on a Milli-Q water system (Bedford, MA, USA). All the other chemicals and reagents we used were analytical grade.

Dimethyl sulfoxide (DMSO), curcumin (Cur), hydrogen peroxide solution $\left(\mathrm{H}_{2} \mathrm{O}_{2}\right),(3 \mathrm{wt} \%$ in $\mathrm{H}_{2} \mathrm{O}$ ), and 3-(4,5-dimethyl-2-thiazolyl)-2,5-diphenyl-2H-tetrazolium bromide (MTT), were purchased from Sigma-Aldrich (St. Louis, MO, USA). The 96-well plates and cell culture dishes were purchased from Corning Inc. (Lowell, MA, USA). Dulbecco's modified Eagle's medium (DMEM), fetal bovine serum (FBS), trypsin, and penicillin-streptomycin solution were purchased from the Gibco ${ }^{\circledR}$ Life Technologies Incorporated Company, (Grand Island, NY, USA).) 


\subsubsection{Instrumental and UPLC-MS/MS Conditions}

The one- and two-dimensional (1D and 2D) NMR spectra was analyzed on a Bruker AVANCE III 400 spectrometer (Fällanden, Switzerland), where the tetramethylsilane (TMS) was used as an internal standard with $\mathrm{CD}_{3} \mathrm{OD}$ as the solvent. All the cultures in this study were carried out under anaerobic conditions, using the Thermo Scientific 1029 Forma Anaerobic System using Oxoid BR0055 as the anaerobic indicator.

The UPLC experiment was carried out on a Shimadzu UPLC instrument equipped with an 8050 series mass spectrometer with the electrospray ionization interface (Shimadzu, Kyoto, Japan). The separation was achieved on a Kinetex ${ }^{\circledR} \mathrm{C}_{18}$ column $(100 \mathrm{~mm} \times 2.1 \mathrm{~mm}, 2.6 \mu \mathrm{m})$ equipped with a Kinetex ${ }^{\circledR} \mathrm{RP}_{18}$ guard column $(30 \mathrm{~mm} \times 2.1 \mathrm{~mm}, 2.6 \mu \mathrm{m})$ at a flow rate of $0.35 \mathrm{~mL} / \mathrm{min}$, analyzed with a gradient elution for $7 \mathrm{~min}$. The UPLC mobile phases consisted of (A) a 1-mM ammonium acetate solution and (B) ACN. The binary gradient program is presented in the Table S1. The column temperature was set at $30^{\circ} \mathrm{C}$ and the injection volume was $2 \mu \mathrm{L}$. Six components and the I.S. were analyzed using multiple reaction monitoring (MRM) modes in the positive (for $\mathrm{P}$ and IP) and negative (for four transformation products) ionization mode, simultaneously. The other parameter settings after optimization were as follows: DL temperature of $250{ }^{\circ} \mathrm{C}$, drying gas flow rate of $10 \mathrm{~L} / \mathrm{min}$, heat block temperature of $400{ }^{\circ} \mathrm{C}$, interface temperature of $300{ }^{\circ} \mathrm{C}$, and nebulizing gas flow of $3 \mathrm{~L} / \mathrm{min}$. The gases used were high purity nitrogen $(99.99 \%)$. The monitoring transitions and relative MS parameters are presented in Table 1.

\subsection{Preparation of Representative Human Gut Bacteria}

This study was authorized and supervised by the Ethics Committee of Peking University Health Science Center, Peking University. All the procedures involving human participants conformed to the ethical standards of the committee. The fresh human feces sample was offered by four healthy Chinese volunteers (two females and two males, 22-30 years old), with at least three months without antibiotics use or gastrointestinal diseases. The feces we collected were immediately premixed and homogenized anaerobically; four grams of fresh feces were suspended with $100 \mathrm{~mL}$ of the GAM broth. We strained the fecal suspensions through nine pieces of gauze, while the subsequent filtrates were incubated in an anaerobic incubator under an anaerobic environment $\left(\mathrm{H}_{2} 5 \%, \mathrm{CO}_{2} 10 \%\right.$, and $\left.\mathrm{N}_{2} 85 \%\right)$ in vitro at $37^{\circ} \mathrm{C}$.

\subsection{Elucidation of the Biotransformation Products from $P$ and IP}

Then, $46 \mathrm{~g}$ GAM broth was dissolved in $1000 \mathrm{~mL}$ of water; the ultrasonic dissolving method was used to make the solution dissolves adequately. The $\mathrm{pH}$ was adjusted to 7.3 before autoclaving at $121^{\circ} \mathrm{C}$ for $20 \mathrm{~min}$. After being cooled to $45^{\circ} \mathrm{C}, 6 \mathrm{mg}$ hematin chloride and $1 \mathrm{mg}$ vitamin $\mathrm{K}$ were added in the broth. Then, $10 \mathrm{~mL}$ of activated bacterial flora were added to GAM solution (1000 mL) and cultivated for $12 \mathrm{~h}$, and $500 \mathrm{mg}$ of $\mathrm{P}$ or IP were added, respectively. The floras were cultivated at $37^{\circ} \mathrm{C}$ for $48 \mathrm{~h}$ in an anaerobic environment, and the cultured suspension was inactivated by being extracted with 2000 mL EtOAc three times. The combined EtOAc layer was evaporated, and the residue was dissolved by $\mathrm{MeOH}$. The extract was simply separated and purified by Sephadex LH-20, by eluting with $\mathrm{MeOH}$ to obtain several fractions. The fractions were determined by HPLC, and some fractions containing the target compounds were injected into the semi-preparative reversed phase HPLC $\mathrm{m}$ while the mobile phase we used was a $30 \%$ ACN aqueous solution containing $0.01 \%$ formic acid.

\subsection{Time Courses of the Biotransformation of P and IP by Human Intestinal Flora}

The biotransformation of $\mathrm{P}$ and IP by human intestinal bacteria was performed in 10 -mL incubation glass tubes containing $3 \mathrm{~mL}$ GAM and $200 \mu \mathrm{L}$ of the intestinal microflora solution, and cultivated for $12 \mathrm{~h}$. The standard solutions of $\mathrm{P}$ and IP were prepared by dissolving accurately weighted $\mathrm{P}$ and IP in DMSO, for which the final concentrations were $0.15 \mathrm{mg} / \mathrm{mL}$ for both. Then, $15 \mu \mathrm{L}$ of $\mathrm{P}$ and IP DMSO solution were added, for which the added volumes of DMSO were no more than $0.5 \%$ of the 
total incubation system [39]. The biotransformation was stopped at $0.25,0.5,1,2,3,4,6,8,10,12$, $16,24,30,36$, and $48 \mathrm{~h}$. A GAM sample without a microflora solution injecting was regarded as the control, and a microflora solution without the compounds was regarded as the blank. Also, the sample was added in the inactivated bacteria liquid to rule out the effect of the culture medium. All of the experiments were performed in triplicate for each time point, which were processed according to the method described mentioned above. Briefly, $50 \mu$ L I.S. $(2000 \mathrm{ng} / \mathrm{mL})$ was pipetted into the bacteria solution, then extracted with $6 \mathrm{~mL}$ EtOAc three times. Each organic layer was carefully transferred to a clean $10 \mathrm{~mL}$ EP tube and dried at $40{ }^{\circ} \mathrm{C}$ under a gentle flow of $\mathrm{N}_{2}$ gas, and the residue was re-dissolved with $100 \mu \mathrm{L}$ mobile phase by a vortex for $1 \mathrm{~min}$, then centrifuged at 15,000 rpm for $10 \mathrm{~min}$. The supernatant was filtered with a $0.22 \mu \mathrm{m}$ filter, and two microliters of the subsequent filtrate were injected into the detective system.

\subsection{Preparation of Standards and Quality Control Samples}

All the prepared solutions were prepared in $\mathrm{MeOH}$, and two sets of mixed stock solution were obtained (2440, 2650, and $1010 \mathrm{ng} / \mathrm{mL}$ for P, P-1, and P-2, and 2530, 2230, and 1070 for IP, IP-1, and IP-2). Then, the solutions further diluted in a pattern of 1:2:2:2.5:4:5:2.5 were applied to generate a series of concentrations of working solutions, which were kept at $-4{ }^{\circ} \mathrm{C}$. The I.S. was prepared with $\mathrm{MeOH}$ at a concentration of $2000 \mathrm{ng} / \mathrm{mL}$. All of the calibration standards and three levels of the quality control (QC) samples (12.20, 610.0, and $1952 \mathrm{ng} / \mathrm{mL}$ for P; 13.25, 662.5, and $2120 \mathrm{ng} / \mathrm{mL}$ for P-1; 5.05, 252.5, and $808 \mathrm{ng} / \mathrm{mL}$ for P-2; 12.65, 632.5, and $2024 \mathrm{ng} / \mathrm{mL}$ for IP; $11.15,557.5$, and $1784 \mathrm{ng} / \mathrm{mL}$ for IP-1; and $5.35,267.5$, and $856 \mathrm{ng} / \mathrm{mL}$ for IP-2 in a drug-free culture medium were prepared by spiking the inactivated bacterial suspensions and relative mixed standard working solutions into the blank culture medium. The linearity ranges were $4.88-2440 \mathrm{ng} / \mathrm{mL}$ for $\mathrm{P}, 5.30-2650 \mathrm{ng} / \mathrm{mL}$ for $\mathrm{P}-1,2.02-1010 \mathrm{ng} / \mathrm{mL}$ for P-2, 5.06-2530 ng/mL for IP, 4.46-2230 ng/mL for IP-1, and 2.14-1070 ng/mL for IP-2, respectively.

\subsection{Evaluation of Cytotoxicity}

The CV was estimated by the MTT assay [40] against HCT116 (human colorectal cells) and Caco-2 (heterogeneous human epithelial colorectal adenocarcinoma cells) cell lines. After the incubation of HCT116 and Caco- 2 cell lines at a density of $2 \times 10^{5}$ cells $/ \mathrm{mL}$ on 96-well plates for $24 \mathrm{~h}$ (Caco-2 was incubated for $36 \mathrm{~h}$ ), the cells were cultured under several test concentrations of compounds for $24 \mathrm{~h}$. Then, $20 \mu \mathrm{L}$ of a MTT test solution $(5 \mathrm{mg} / \mathrm{mL})$ was added to each well and incubated for $4 \mathrm{~h}$. The formazan was fully dissolved by $100 \mu \mathrm{L}$ DMSO and the OD (average optical density) values were detected by a microplate reader (Multiskan Mk3, Thermo) at $490 \mathrm{~nm}$. with a $650 \mathrm{~nm}$ reference wavelength. The tests were performed separately three times. The cell viabilities were calculated as the percent account for the control group as the following equation:

$$
\text { Cell viability }(\%)=\left[\left(A_{\mathrm{H} 2 \mathrm{O} 2}-A_{\text {blank }}\right) /\left(A_{\text {contral }}-A_{\text {blank }}\right)\right] \times 100 \%
$$

\subsection{Alleviating Oxidative Stress Caused by $\mathrm{H}_{2} \mathrm{O}_{2}$ in HCT116 and Caco-2 cells}

The alleviating oxidative stress effects of six compounds against two cell lines were conducted, and the oxidative stress model was established by the $\mathrm{H}_{2} \mathrm{O}_{2}$. The cells were cultured in 96-well plate as described in the above-mentioned, which were the deal with several test concentrations of $\mathrm{H}_{2} \mathrm{O}_{2}$ for 6 $\mathrm{h}$ to explored optimal concentration. The CV was detected by the MTT test. After incubating the cells according to the method mentioned above, the DMEM medium was discarded and treated with $100 \mu \mathrm{L}$ of FBS-free DMEM medium containing different concentrations $(2.5,5$, and $10 \mu \mathrm{M})$ of six compounds for $2 \mathrm{~h}$. Then, the $\mathrm{H}_{2} \mathrm{O}_{2}$ was added into each well (700 $\mu \mathrm{M}$ for HCT116, and $900 \mu \mathrm{M}$ for Caco-2) and incubated for $6 \mathrm{~h}$. The control group contained FBS-free DMEM, and no $\mathrm{H}_{2} \mathrm{O}_{2}$ was added to the cells, whereas the FBS-free DMEM without cells or $\mathrm{H}_{2} \mathrm{O}_{2}$ in blank wells. The cells were treated with $\mathrm{H}_{2} \mathrm{O}_{2}$ and Cur $(10 \mu \mathrm{M})$ as a positive control group. All of the CVs were detected by the MTT assay mentioned above. All of the experiments were conducted for three replicate wells in three parallel experiments. 


\subsection{Statistical Analysis}

The data were calculated using SPSS statistics package v.20.0 (SPSS Inc., Chicago, IL, USA) and GraphPad Prism (GraphPad software Inc., San Diego, CA, USA). The results are showed as the mean \pm standard deviation (SD), and the differences between the test group and the control group were analyzed by Student's $t$-test, for which the results were recognized significant at ${ }^{*} p<0.05,{ }^{* *} p<0.01$, and ${ }^{* * *} p<0.001$.

\section{Conclusions}

The research demonstrated that human intestinal bacteria transformation is an essential part of the metabolism of $P$ and IP in vivo, for which the reduction reaction at the $\alpha, \beta$-unsaturated lactone ring of the coumarin skeleton and methylation are the main pathways. The results demonstrated that the antioxidant stress activity of PC may rely on the metabolism of P and IP by intestinal bacteria for the greater activity of the metabolic products. However, further studies should be done in order to illustrate the mechanism of action of the pharmacological activity of IBD.

Supplementary Materials: The following are available online. Full IR, MS, and NMR spectra for compound IP-2, and other supplementary information of this research.

Author Contributions: The list authors contributed to this work are as follows: X.-W.Y. and L.L. conceived and designed the experiments; L.L., L.Z., Z.-X.C., X.-Y.L., and W.X. performed the research and analyzed the data; L.L. wrote the paper. X.-W.Y. polished the paper; and X.-W.Y. acquired the funding for the research. All of the authors read and approved the final manuscript.

Funding: This research was funded by National Natural Science Foundation of China, grant number " 81773865 " and the National Key Technology R \& D Program of China, grant number "2011BAI07B08".

Conflicts of Interest: The authors have declared no conflicts of interest.

\section{References}

1. Uikey, S.; Yadav, A.S.; Sharma, A.K.; Rai, A.K.; Raghuwanshi, D.K.; Badkhane, Y. The botany, chemistry, pharmacological and therapeutic application of Psoralea corylifolia L.-A Review. Int. J. Phytomedicine 2010, 2, 100-107. [CrossRef]

2. Chinese Pharmacopoeia Commission. Pharmacopoeia of the People's Republic of China; Medical Science and Technology Press: Beijing, China, 2010; Volume 1, p. 174.

3. Li, C.C.; Wang, T.L.; Zhang, Z.Q.; Yang, W.Q.; Wang, Y.F.; Chai, X.; Wang, C.H.; Li, Z. Phytochemical and pharmacological studies on the genus Psoralea: A Mini Review. Evid Based Complement. Alternat Med. 2016, 2016, 1-17.

4. Arya, P.; Gothalwal, R. Seed dormancy testing and germination frequency determination of Psoralea corylifolia L., an endangered medicinal plant. Tropical Plant. Res. 2017, 4, 49-54. [CrossRef]

5. Nabi, N.G.; Shrivastava, M.; Dhar, R.S. Endangered medicinal plant Psoralea corylifolia: Traditional, phytochemical, therapeutic properties and micropropagation. UK J. Pharm. Biosci. 2017, 5, 40-46. [CrossRef]

6. Kiran, B.; Lalitha, V.; Raveesha, K.A. Antibacterial activity of bioactive compound isolated from seeds of Psoralea corylifolia L. against Gram positive and Gram negative bacterial species. J. Pharmacy Res. 2012, 5, 144-146.

7. Seo, E.; Kang, H.; Oh, Y.S.; Jun, H.S. Psoralea corylifolia L. seed extract attenuates diabetic nephropathy by inhibiting renal fibrosis and apoptosis in streptozotocin-induced diabetic mice. Nutrients 2017, 9, 828. [CrossRef] [PubMed]

8. Yi, L.T.; Li, Y.C.; Pan, Y.; Li, J.M.; Xu, Q.; Mo, S.F.; Qiao, C.F.; Jiang, F.X.; Xu, H.X.; Lu, X.B.; et al. Antidepressant-like effects of psoralidin isolated from the seeds of Psoralea corylifolia in the forced swimming test in mice. Prog. Neuro-Psychopharmacol. Biol. Psychiatry 2008, 32, 510-519. [CrossRef] [PubMed]

9. Jan, S.; Parween, T.; Siddiqi, T.O. Mahmooduzzafar, anti-oxidant modulation in response to gamma radiation induced oxidative stress in developing seedlings of Psoralea corylifolia L. J. Environ. Radioact. 2012, 113, 142-149. [CrossRef] [PubMed] 
10. Kiran, B.; Lalitha, V.; Raveesha, K.A. Antifungal activity of aqueous and solvent extracts of seeds of Psoralea corylifolia L. against seed borne fungi of maize. Int. J. Pharm. Life Sci. 2011, 2, 1133-1136.

11. Chen, C.H.; Hwang, T.L.; Chen, L.C.; Chang, T.H.; Wei, C.S.; Chen, J.J. Isoflavones and anti-inflammatory constituents from the fruits of Psoralea corylifolia. Phytochemistry 2017, 143, 186-193. [CrossRef] [PubMed]

12. Chen, Y.; Wu, Y.; Song, J.C. Research progress of the chemical constituents and bioactivity of Psoralea corylifolia. Pract. Pharm. Clin. Rem. 2016, 19, 1184-1188.

13. Im, A.R.; Chae, S.W.; Zhang, G.J.; Lee, M.Y. Neuroprotective effects of Psoralea corylifolia Linn seed extracts on mitochondrial dysfunction induced by 3-nitropropionic acid. BMC Complement. Altern. 2014, 14, 370. [CrossRef] [PubMed]

14. Wu, C.R.; Chang, C.L.; Hsieh, P.Y.; Lin, L.W.; Ching, H. Psoralen and isopsoralen, two coumarins of Psoraleae Fructus, can alleviate scopolamine-induced amnesia in rats. Planta. Medica. 2007, 73, 275-278. [CrossRef] [PubMed]

15. Shen, L.X.; Zhao, P.W.; Niu, J.Z.; Wang, J.F. Effect of psoralen on proliferation of human breast carcinoma cells. Chin. Pharmacol. Bull. 2007, 23, 1448-1451.

16. Li, X.M.; Yang, Q.; Li, X.B.; Cheng, Q.; Zhang, K.; Han, J.; Zhao, J.N.; Liu, G.; Zhao, M.G. Estrogen-like neuroprotection of isopsoralen against spinal cord injury through estrogen receptor ER $\alpha$. Metab. Brain Dis. 2017, 32, 1-7. [CrossRef] [PubMed]

17. Wang, Y.; Hong, C.; Zhou, C.; Xu, D.; Qu, H.B. Screening antitumor compounds psoralen and isopsoralen from Psoralea corylifolia L. seeds. Evid. Based Complement. Alternat. Med. 2011, 2011, 363052. [CrossRef] [PubMed]

18. Shim, S.H.; Kim, J.C.; Jang, K.S.; Choi, G.J. Anti-oomycete activity of furanocoumarins from seeds of Psoralea corylifolia against Phytophthora infestans. Plant. Pathol. J. 2009, 25, 103-107. [CrossRef]

19. Wu, C.; Sun, Z.; Ye, Y.; Han, X.; Song, X.; Liu, S. Psoralen inhibits bone metastasis of breast cancer in mice. Fitoterapia 2013, 91, 205-210. [CrossRef] [PubMed]

20. Kim, J.Y.; Oh, K.Y.; Kim, J.Y.; Ryu, H.W.; Jeong, T.S.; Park, K.H. Polyphenols displaying tyrosinase inhibition from the seed of Psoralea corylifolia. J. Korean Soc. Appl. Biol. Chem. 2010, 53, 427-432. [CrossRef]

21. Xiao, G.D.; Li, G.W.; Chen, L.; Zhang, Z.J.; Yin, J.J.; Wu, T.; Cheng, Z.H.; Wei, X.H.; Wang, Z.T. Isolation of antioxidants from Psoralea corylifolia fruits using high-speed counter-current chromatography guided by thin layer chromatography-antioxidant autographic assay. J. Chromatogr. A 2010, 1217, 5470-5476. [CrossRef] [PubMed]

22. Carini, F.; Tomasello, G.; Jurjus, A.; Geagea, A.; Kattar, S.; Damiani, P.; Sinagra, E.; Rappa, F.; David, S.; Cappello, F.; et al. Colorectal cancer and inflammatory bowel diseases: Effects of diet and antioxidants. J. Biol. Regul. Homeost. Agents 2017, 31, 791-795. [PubMed]

23. Chen, X.M.; Yang, Y.F.; Zhang, Y.T. Isobavachalcone and bavachinin from Psoraleae Fructus modulate A $\beta 42$ aggregation process through different mechanisms in vitro. FEBS Lett. 2013, 587, 2930-2935. [CrossRef] [PubMed]

24. Xu, Q.X.; Hu, Y.; Li, G.Y.; Xu, W.; Zhang, Y.T.; Yang, X.W. Multi-target anti-alzheimer activities of four prenylated compounds from Psoralea Fructus. Molecules 2018, 23, 614. [CrossRef] [PubMed]

25. Zhang, L.Q.; Yang, X.W.; Zhang, Y.B.; Zhai, Y.Y.; Xu, W.; Zhao, B.; Liu, D.L.; Yu, H.J. Biotransformation of phlorizin by human intestinal flora and inhibition of biotransformation products on tyrosinase activity. Food Chemistry 2012, 132, 936-942. [CrossRef]

26. Feng, L.; Wang, L.; Jiang, X. Pharmacokinetics, tissue distribution and excretion of coumarin components from Psoralea corylifolia L. in rats. Arch. Pharm. Res. 2010, 33, 225-230. [CrossRef] [PubMed]

27. Yang, Y.F.; Zhang, Y.B.; Chen, Z.J.; Zhang, Y.T.; Yang, X.W. Plasma pharmacokinetics and cerebral nuclei distribution of major constituents of Psoraleae fructus in rats after oral administration. Phytomedicine 2018, 38, 166-174. [CrossRef] [PubMed]

28. Yan, D.M.; Chang, Y.X.; Wang, Y.F.; Liu, E.W.; Li, J.; Kang, L.Y.; Gao, X.M. In vivo pharmacokinetics of bakuchiol after oral administration of bakuchiol extraction in rat plasma. J. Ethnopharmacol. 2010, 128, 697-702. [CrossRef] [PubMed]

29. Marumoto, S.; Miyazawa, M. Microbial reduction of coumarin, psoralen, and xanthyletin by Glomerella cingulata. Tetrahedron 2011, 67, 495-500. [CrossRef]

30. Orabi, K.Y.; Sayed, K.A.E. Biocatalytic studies of the furanocoumarins angelicin and chalepensin. Nat. Prod. Commun. 2007, 2, 565-569. [CrossRef] 
31. Kim, L.; Kim, Y.; Kwon, O.; Ji, Y.K. Antioxidant activities of ethanolic and acidic ethanolic extracts of astringent persimmon in $\mathrm{H}_{2} \mathrm{O}_{2}$-stimulated Caco-2 human colonic epithelial cells. Food Sci. Biotechnol. 2017, 26, 1-7. [CrossRef] [PubMed]

32. Rosignoli, P.; Fuccelli, R.; Sepporta, M.V.; Fabiani, R. In vitro chemo-preventive activities of hydroxytyrosol: The main phenolic compound present in extra-virgin olive oil. Food Funct. 2016, 7, 301-307. [CrossRef] [PubMed]

33. Guo, J.N.; Weng, X.C.; Hou, W.; Li, Q.H.; Bi, K.S. Antioxidants from a Chinese medicinal herb-Psoralea corylifolia L. Food Chem. 2005, 91, 287-292.

34. Rice-Evans, C.A.; Miller, N.J.; Paganga, G. Structure-antioxidant activity relationships of flavonoids and phenolic acids. Free Radic. Biol. Med. 1996, 20, 933-956. [CrossRef]

35. Lee, D.S.; Kim, Y.S.; Ko, C.N.; Cho, K.H.; Bae, H.S.; Lee, K.S.; Kim, J.J.; Park, E.K.; Kim, D.H. Fecal metabolic activities of herbal components to bioactive compounds. Arch. Pharmacal Res. 2002, 25, 165-169. [CrossRef] [PubMed]

36. Sousa, T.; Paterson, R.; Moore, V.; Carlsson, A.; Abrahamsson, B.; Basit, A.W. The gastrointestinal microbiota as a site for the biotransformation of drugs. Int. J. Pharm. 2009, 363, 1-25. [CrossRef] [PubMed]

37. Liu, H.; Bai, Y.J.; Chen, Y.Y.; Zhao, Y.Y. Studies on chemical constituents from seed of Psoralea corylifolia. Zhongguo Zhong Yao Za Zhi 2008, 33, 1410-1412. (In Chinese) [PubMed]

38. Deng, G.G.; Yang, X.W.; Zhang, Y.B.; Wei, X.U.; Wei, W.; Li, Z.G. Chemical constituents from lipophilic parts in roots of Angelica dahurica cv.Yubaizhi. Zhongguo Zhong Yao Za Zhi 2017, 42, 2102-2109. (In Chinese) [PubMed]

39. Yang, X.W.; Xu, W. Establishment of model and standard operation procedure for biotransformation of chemical constituents of traditional Chinese medicine by human intestinal bacteria. Zhongguo Zhong Yao Za Zhi 2011, 36, 19-26. (In Chinese) [PubMed]

40. Carmichael, J.; Mitchell, J.B.; Degraff, W.G.; Gamson, J.; Gazdar, A.F.; Johnson, B.E.; Glatstein, E.; Minna, J.D. Chemosensitivity testing of human lung cancer cell lines using the MTT assay. Br. J. Cancer 1985, 57, 540-547. [CrossRef] [PubMed]

Sample Availability: Samples of the compounds are not available from the authors.

(C) 2019 by the authors. Licensee MDPI, Basel, Switzerland. This article is an open access article distributed under the terms and conditions of the Creative Commons Attribution (CC BY) license (http://creativecommons.org/licenses/by/4.0/). 